\title{
SOCKET SHIELD AND BIOACTIVE GLASS AROUND ANTERIOR MAXILLA IMMEDIATE DENTAL IMPLANTS
}

\author{
Maher Abdullatif Walid* and Mohamed Ahmed Alkhodary**
}

\begin{abstract}
Introduction: This study aimed at testing the effect of the socket shield technique on the maintenance of the labial plate of bone and the change in position of its surrounding gingival soft tissues upon the immediate placement of 3 different dental implants systems, with a bone graft material filling the defects around the implants, followed by clinical and radiographic evaluation using the cone beam computed tomography after 4 and 12 months of loading.
\end{abstract}

Materials and Methods: Three groups, 6 male patients each, having a failing central or lateral maxillary incisor, had their failing tooth partially extracted, with the remaining tooth half reduced to be the socket shield, then the 3 groups received 3 different dental implants systems, the Tapered Internal implant RBT Laser-Lock for group I, the Touareg-S implant for group II, and group III received the Nobel Active implant. Then, the Novabone putty bone graft was dispensed in the space between the implant and the shield and covered with a customized healing abutment. After 4 months of healing, the patients were provided with definitive restorations, and followed after 4 and 12 months for gingival recession, papillae filling the interdental spaces, and CBCT evaluation of the labial plate of bone width and vertical resorption. Each result was then statistically analyzed.

Results: For all the cases in the study, no implant failed, no gingival recession was recorded, and the interdental papillae filled their spaces in most of the cases. also, no significant changes were recorded for the labial plate of bone width or height.

Conclusions: The socket shield technique was able to maintain the labial plate of bone and the position of the overlying free gingival margin, with the neighboring interdental papillae showing least dimensional changes.

KEY WORDS: Socket shield, immediate implants, bioactive glass, CBCT.

* Lecturer, Department of Periodontology and Oral Medicine, College of Dentistry, Qassim University, Kingdom of Saudi Arabia.

** Associate Professor, Head of Department of Prosthetic Dental Sciences, College of Dentistry, Qassim University, Kingdom of Saudi Arabia, Associate Professor, Department of Prosthodontics, Faculty of Dentistry, Alexandria University, Egypt. 


\section{INTRODUCTION}

Partial tooth extraction, the root membrane, or the socket-shield technique is recently suggested to minimize the dimensional changes of the facial plate of the maxillary and mandibular alveolar bone with immediate implants after teeth extraction. However, some histologic evidence documented loss of bone, formation of cementum and fibrous tissue between the implant surfaces and the shield. ${ }^{1-5}$

Other studies were in favor of the socket shield, documenting successful distance and contact osteogenesis, despite an almost half centimeter space from the implant to the socket shield with no bone grafting or membrane assistance, and maintenance of the labial plate of bone as if no tooth extraction took place. ${ }^{6-8}$

Although, there are no determining guidelines in regards to the type of biomaterials, or surgical techniques used, an atraumatic extraction technique and a suitable bone graft material, can efficiently reduce vertical and horizontal bone resorption after teeth extraction. ${ }^{9-14}$

The osteostimulative properties of bone graft materials can lead to new bone formation within 4-6 months of healing and tend to increase over time which is ideal to ensure good quality of bone and sufficient thickness of the overlying soft tissue for long-term implant survival. ${ }^{15-25}$

Compared to delayed implants, immediate implants in the anterior maxilla encounter some adverse esthetic outcomes resulting from labial plate resorption and gingival recession. 26-28 However, improved implant macro-mechanical design, and surface treatments that can ensure long term biointegration, were found to minimize such complications in carefully selected patients. ${ }^{29-38} \mathrm{In}$ addition, flapless placement of immediate implants was found to provide numerous benefits, such as decreased trauma, short recovery time, less pain, reduced rate of infection and bone resorption, and eventually improved patient compliance. ${ }^{41-47}$
Immediate implants provisionalization is noninferior to delayed provisionalization, however, it is technique-sensitive in the esthetic region of the mouth. ${ }^{48-57}$ Another approach than immediate provisionalization is to use customized healing abutments which supports the free gingival margin, maintains or regenerates the interproximal papillae, and facilitates the production of physiologic proximal contacts and emergence profiles of the definitive restorations, which in turn lead to long term maintenance of such soft tissues architectures. ${ }^{32,58-62}$

The dental implants clinical post-operative follow-up using periapical radiography was found to provide a better diagnostic accuracy that is higher and more valid than the cone beam computed tomography (CBCT) at detecting peri-implant bone defects. ${ }^{63}$ However, periapical radiography provides a two dimensional visualization and is not able to show mid-buccal and mid-lingual bone defects around the dental implants, whereas in the CBCT cross sectional images, the distance measurement tool can measure the vertical bone resorption and the thickness of the labia bone plate with great accuracy when specific voxel size and mille-amperage were used. Additionally, radiographic analysis using CBCT before extraction was strongly advised to choose the appropriate dental implant dimensions and treatment approach. ${ }^{64-78}$

Since there is no guarantee that immediate implants and/or bone grafting can avoid the consequences of exodontia, this study aimed to test the effect of socket shield technique on maintaining the labial plate of bone and surrounding gingival tissues using clinical and CBCT evaluation.

\section{MATERIALS AND METHODS}

Eighteen male patients were selected from the out-patient clinics at the College of Dentistry, Qassim University-KSA. The procedures were explained to the patients before having their informed consent signed. The approval of the ethical committee of the college was obtained with a condition that a negative 
control group was not to be included to guarantee that every patient is gaining the maximum benefit of the treatment modality under study.

Patients inclusion criteria were as follows: (1) age from 25 to 45 years old; (2) good oral hygiene; (3) having a single failing tooth in the anterior maxilla, namely the central or the lateral incisors with sound neighboring teeth; (4) the failing tooth and its neighbors must have defect free mucosa; (5) thick gingival biotype; (6) good alveolar bone all around the failing tooth.

Patients exclusion criteria were as follows: (1) bruxism; (2) systemic diseases affecting bone (3) smoking; (4) periodontal disease; (5) presence of a chronic abscess, or an abscess with a fistulous tract; (6) physiologically thin labia bone plate.

Random allocation of the patients to 3 groups of 6 patients each was done blindly, the groups then had similar procedures of base line CBCT for pre-operative planning of implant placement (fig. 1-3), partial tooth extraction and preparation of the socket shield, dental implant placement, bone graft injection around the implant, making of a custom made healing abutment, definitive prosthetic restoration, 4 months healing, clinical and CBCT follow up after 4 and 12 months of loading.

The condemned tooth, in figure $4 \mathrm{a}$, was locally anesthetized, then root sectioning, as seen in figure $4 \mathrm{~b}$, in two segments with a long shaft bur (Komet Dental, Germany) mounted on a high-speed handpiece with water cooling was done. Using a \#1 periotome (Nordent, USA) the periodontal ligament of the palatal segment was severed carefully, and then palatal segment was extracted with meticulous care to maintain the labial root segment attached to labial bone plate as seen in figure $4 \mathrm{c}$. The labial segment is turned into the socket shield, as seen in figure $4 d$, by vertical reduction to one millimeter occlusal to the labial bone plat ledge, and by thinning of its length and width using a large rose head diamond bur (Komet Dental, Germany) attached to a high-speed hand-piece with water cooling, this was followed

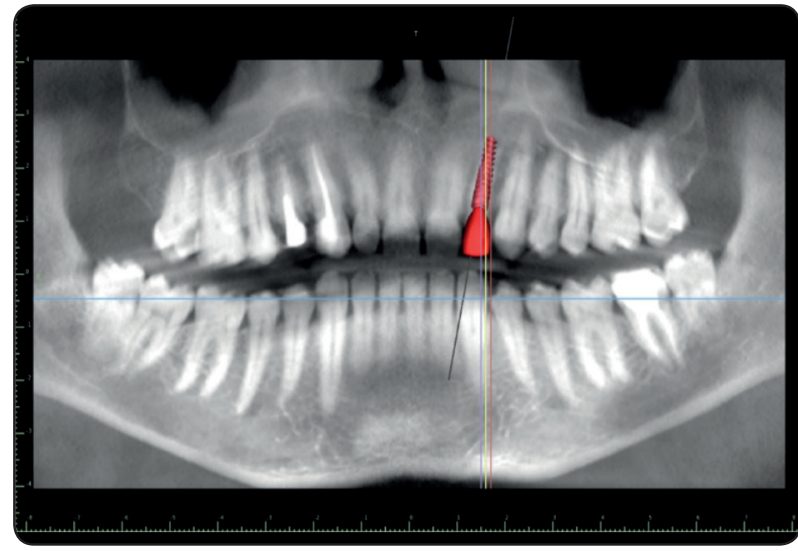

Fig. (1) : preoperative panoramic X-ray reconstructed from the $\mathrm{CBCT}$ and used for implant placement planning.

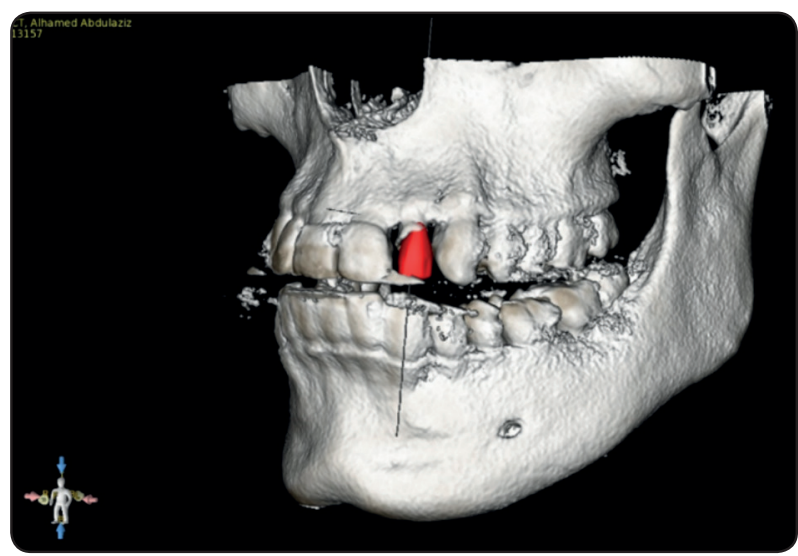

Fig. (2) CBCT 3 dimensional reconstruction of the patient skull with the proposed restoration in red.

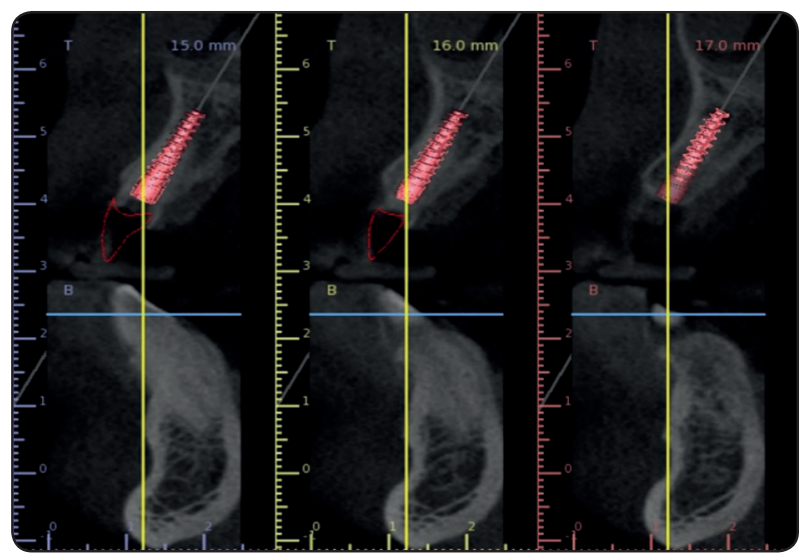

Fig. (3) CBCT cross sectional images showing the potential implant and crown position 


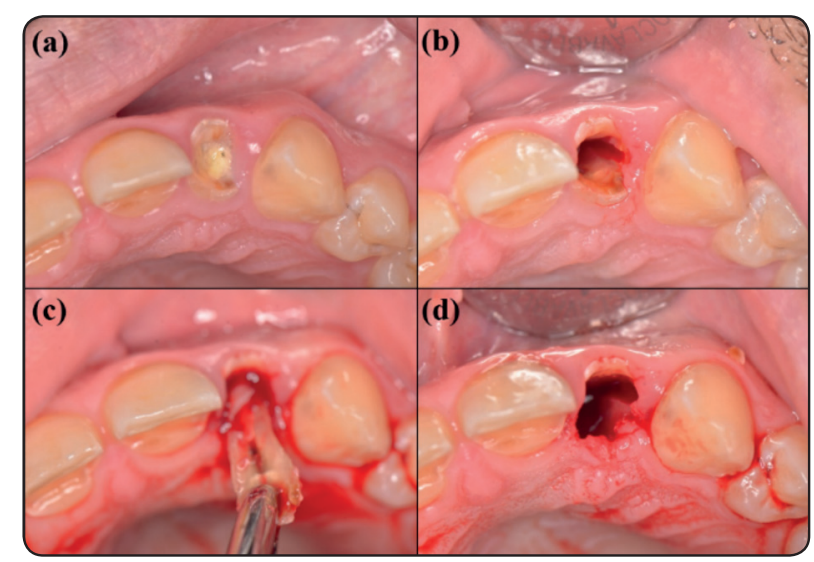

Fig. (4) Tooth extraction and preparation of the socket shield: (a) pre-operative clinical photograph of the failing tooth, (b) sectioning of the failing tooth into labial and palatal segments, (c) extraction of the palatal segment, (d) the labial segment prepared to be the socket shield.

by curettage, saline irrigation, and inspection of the socket shield for mobility.

The implant osteotomy was then prepared sequentially with more palatal bias in the socket, and apical drilling to the fundus of the socket so that after implant placement its platform was apical to the free gingival margin by $4 \mathrm{~mm}$ as seen in figure $5 \mathrm{a}$, and $\mathrm{b}$. Group I received the Tapered Internal implant RBT Laser-Lock (Biohorizon, USA) of 3.8 $\mathrm{mm}$ diameter and $15 \mathrm{~mm}$ length, group II received the Touareg-S implant (Adin, Belgium) of 3.5 $\mathrm{mm}$ and $16 \mathrm{~mm}$ length, and group III received the NobelActive implant (Nobel biocare, Sweden) of $3.5 \mathrm{~mm}$ diameter and $13 \mathrm{~mm}$ length. The diameters of the 3 implant systems were close to each other, however, the different lengths used were to make sure that there are $4 \mathrm{~mm}$ of the implant apical to the fundus of the extraction socket to ensure primary stability. Then. the Novabone ® (NOVEBONE PUTTY, USA) putty was dispensed in the defect between the implant and the shield as seen in figure $5 \mathrm{~b}$ and $\mathrm{c}$.

Following the bone graft injection, customized healing abutments were fabricated chair-side using titanium or plastic temporary abutment, that were attached to the implants, and around

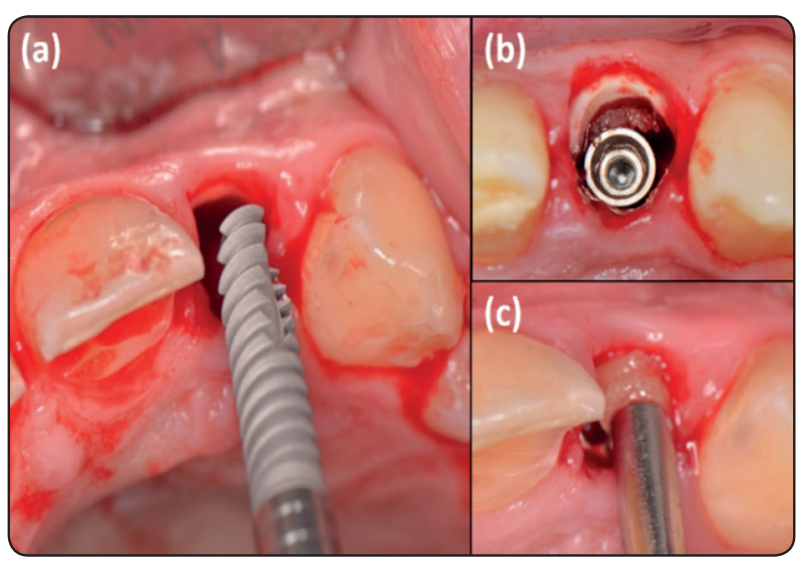

Fig. (5) Implant and bone graft placement: (a) immediate implant placement, (b) initial injection of the bone graft, (c) bone graft filling the space between the implant and the socket shield.

which light cured flowable composite (Filtek ${ }^{\mathrm{TM}}$ Bulk Fill Flowable Restorative, 3m, USA) was used to copy as much as possible the emergence profile of the extracted teeth in order to support the surrounding soft tissues. The constructed abutments were finished to $\mathrm{S}$-shape emerging profile, as seen in figure $6 \mathrm{a}$ and $\mathrm{b}$, to ensure adequate space with the buccal shield. Then the customized healing abutments were screwed in place as seen in figure $6 \mathrm{c}$, and their contours were verified using periapical $\mathrm{x}$-rays as seen in figure $7 \mathrm{a}-\mathrm{c}$, then, the patients were given the homecare instructions and mouth rinses in addition to the routine oral hygiene measures.

After 4-month the customized healing abutments were removed for final impression making as seen in figure 8a. Using rubber base materials (Express TM VPS impression material, putty and light body (3M, USA), a one step, open top tray, an implant level impression was made using an impression coping surrounded by light cured composite duplicating the emergence profile as seen in figure $8 \mathrm{~b}$, after making the impression, an implant analogue was secured to the impression coping as seen in figure 9a, and the impression was poured into hard stone. The patients were provided with temporary crowns that had their emergence profile perfected. Finally, after selection of the most suitable shade, each patient was provided with the definitive porcelain- 
fused-to-metal crown that duplicated the temporary crown emergence profile using a light body index as seen in figure $9 \mathrm{~b}$ and $\mathrm{c}$. In order to change this crown into a screw retained rather than cemented prosthesis, it was first permanently cemented to the definitive custom abutment extra-orally, as seen in figures 10a, and b, using a resin cement (RelyX Unicem Self-Adhesive, 3M, USA), this helped to prevent excess cement escape into implant sulcular area. This crown was torqued in place, using $35 \mathrm{~N} \backslash$ $\mathrm{CM}$, as seen in figure 10c.

In the clinical and radiographic follow-up, the following parameters were assessed at the time of definitive crown insertion, and after 4 and 12 months of loading as follows:

The implant osseointegration success or failure

Papillae filling of the interdental space using the Jemt papilla score ${ }^{80}$ which assessed the shape of the papilla as follows: (0) no papilla is present; (1) less than half of the interdental space is filled with the papilla; (2) half or more of the interdental space is filled with the papilla; (3) the interdental space is filled with the papilla; (4) the papilla is .hyperplastic

Gingival recession was evaluated using a graduated plastic tape to measure the distance from the incisal edge of the definitive crown to the zenith of the gingi.val margin

CBCT evaluation using the dental CBCT scanner (GALILEOS Comfort Plus, Sirona, Germany) which was operated at $98 \mathrm{kV}, 3-6 \mathrm{~mA}$, a focal spot size of $0.5 \mathrm{~mm}$, with centered focal planes to the implant, and reconstructed the cross sectional images with the soft.(ware SIDEXIS XG (Sirona, Germany

Thickness of the labial plate of bone was measured with the distance measuring tool of the software, at $1 \mathrm{~mm}$ from the implant shoulder to provide the cervical width and $5 \mathrm{~mm}$ from the implant platform to provide the middle .section width as seen in figure 11

Vertical resorption of the labial plate of bone was measured from a horizontal line, extending from the implant platform and perpendicular to the implant surface, to the alveolar ledge as seen in .figure 11

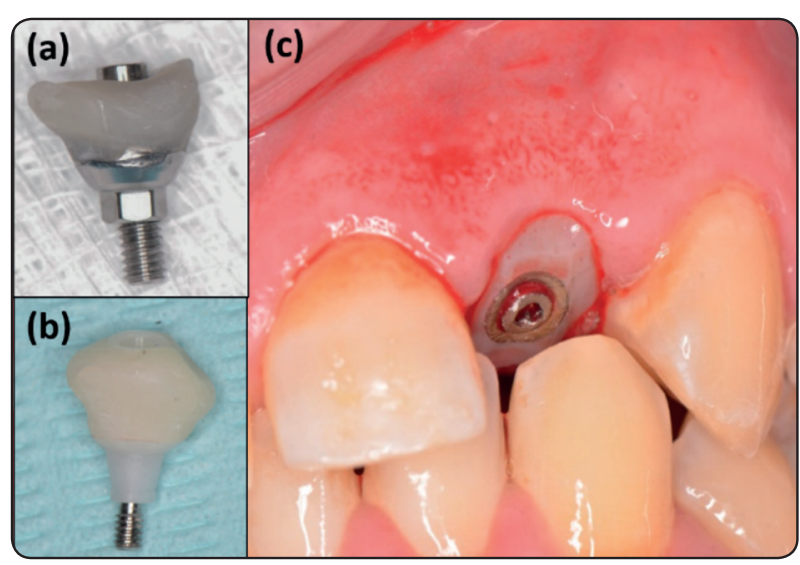

Fig. (6) The screw retained customized healing abutment: (a) the customized healing abutment prepared using a temporary titanium abutment and a light cured flowable composite resin, (b) the customized healing abutment made using a plastic temporary abutment, (c) the contoured customized healing abutment screwed in place to support the periimplant soft tissues during healing.

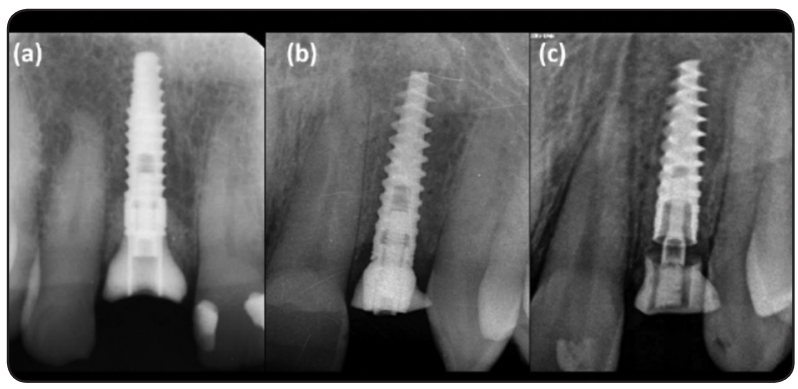

Fig. (7) Peri-apical x-rays immediately following screwing the customized healing abutment, (a) the Tapered Internal implant RBT Laser-Lock implant, (b) the Touareg-S Adin implant, and (c) the NobelActive implant, note the space between this implant and the customized healing abutment due to the use of a plastic temporary abutment. 


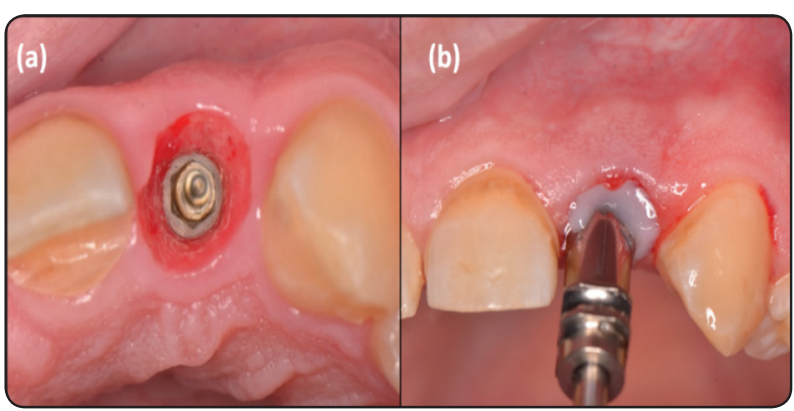

Fig. (8) removal of the customized healing abutment for final impression, (a) note the fresh bleeding mucosal surface which indicated the attachment of the soft tissues to the healing abutment, (b) attachment of an open top tray impression coping to the implant and filing the emergence profile space with flowable light cured composite to duplicate its contours.

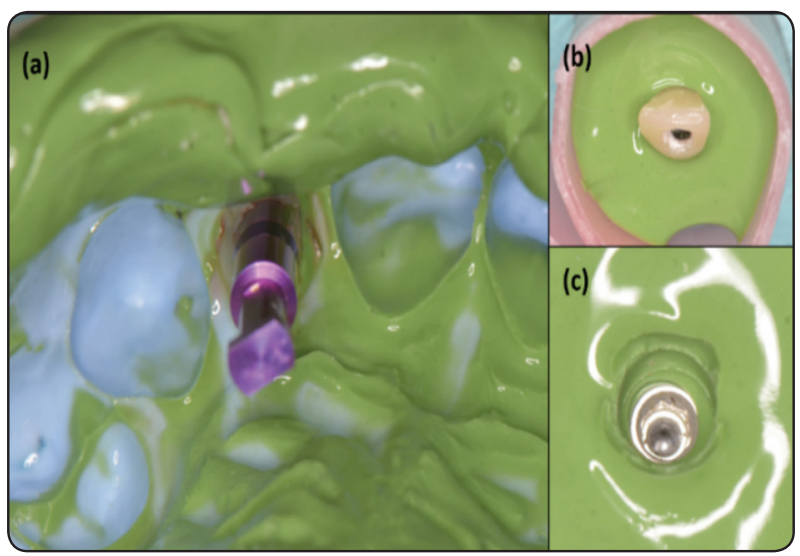

Fig. (9) Final impression and creation of the emergence profile, (a) the implant analogue attached to the impression coping in the final impression, (b) the screw retained temporary crown attached to an implant analogue and invested in in a cylinder made of light body impression material to duplicate the carefully reproduced emergence profile, (c) the temporary crown removed and the light body index is used to create the same emergence profile in the definitive crown.

Finally, the Statistical analysis tests used in this study were the $\mathrm{T}$ Test for 2 dependent means to analyze the results of the change in papilla score, the Kruskal-Wallis test to analyze the differences in gingival recession, and values of the CBCT labial plate thickness and corresponding vertical resorption were analyzed using the Mann-Whitney U-test.

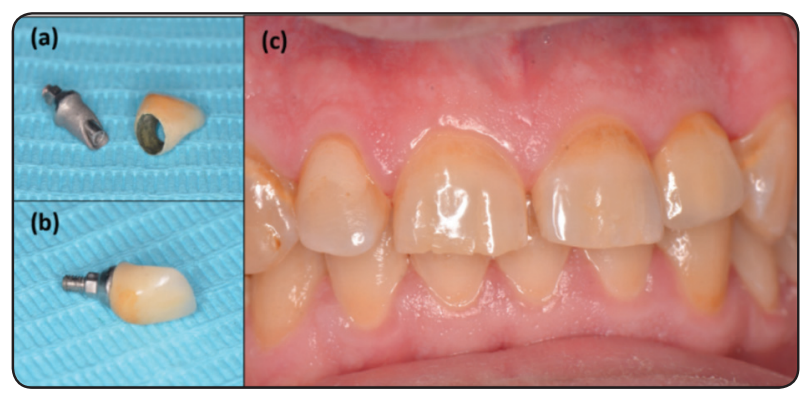

Fig. (10) The definitive restoration: (a) the definitive crown is made with a hole I its palatal surface to be screwed rather cemented to the implant, (b) the definitive crown cemented to the permanent abutment and excess cement removed, (c) the definitive crown and abutment screwed to the implant in the patient mouth, in this clinical photograph the implant restored the tooth number 22 .

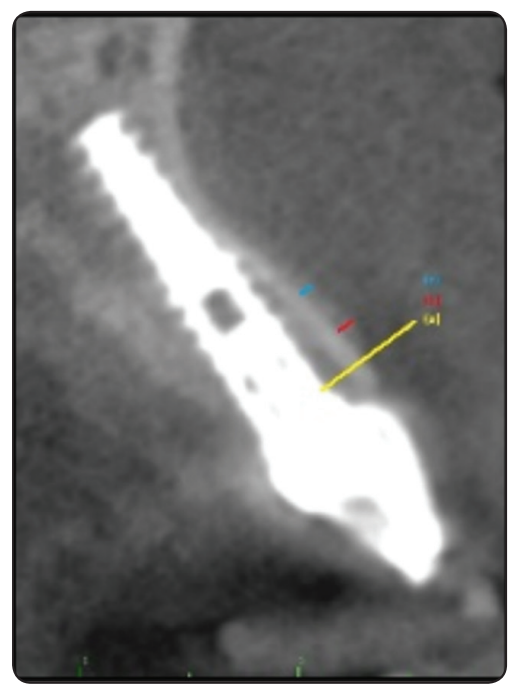

Fig. (11) CBCT follow up of the labial plate of bone: the vertical resorption of the labial plate of bone was measured from the yellow line perpendicular to the implant surface, emerging at the implant abutment connection. The red line represents the cervical width of the labial plate of bone measured $1 \mathrm{~mm}$ from the implant platform. The blue line represents the mid-section width of the labial plate of bone measured $5 \mathrm{~mm}$ from the implant platform.

\section{RESULTS}

The current work evaluated the socket shield technique effect on the labial plate of bone, and its surrounding soft tissues, upon the restoration of a maxillary central or a lateral incisor tooth using an immediate dental implant and a bone graft. The participants of this study were carefully chosen, and 
were given strict instructions about maintenance of good oral hygiene. Meticulous surgical and prosthetic techniques were followed to ensure best clinical outcomes. Table 1 shows the distribution of the follow up parameters values recorded during this one-year clinical trial, and table 2 shows the results of the statistical analysis of the results.

The implant stability: All the implants of the 3 groups were clinically stable, and none of them required removal.

The interdental papilla: A single score was used to describe the papillae on the mesial and distal of each implant, with the lower score being used, for example if the mesial papilla score is 3 and the distal papilla score is 2 , then a score of 2 was used to describe the papilla score for this implant. All 3 groups showed a similar distribution and no significant differences in the papilla scores, where the papillae filled their spaces around the 3 implant systems used.

Gingival recession: No significant gingival recession was recorded from definitive crown insertion to the 4 months and 1-year follow-up in the 3 treatment groups.

Radiographic evaluation: The CBCT readings in this study were recorded twice by two different dental

TABLE (1) Distribution of follow up parameters values

\begin{tabular}{|c|c|c|c|c|c|c|c|c|c|c|c|c|c|c|}
\hline \multirow[b]{3}{*}{ 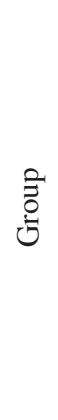 } & \multirow{3}{*}{ 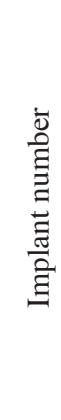 } & \multirow{2}{*}{\multicolumn{2}{|c|}{ 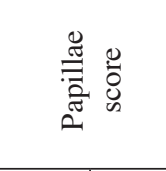 }} & \multirow{2}{*}{\multicolumn{2}{|c|}{ 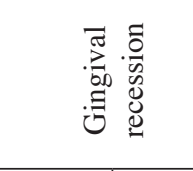 }} & \multicolumn{9}{|c|}{ The labial plate of bone } \\
\hline & & & & & & \multicolumn{3}{|c|}{$\begin{array}{c}\text { At definitive crown } \\
\text { insertion }\end{array}$} & \multicolumn{3}{|c|}{$\begin{array}{c}4 \text { months after } \\
\text { definitive crown } \\
\text { insertion }\end{array}$} & \multicolumn{3}{|c|}{$\begin{array}{l}12 \text { months after } \\
\text { definitive crown } \\
\text { insertion }\end{array}$} \\
\hline & & 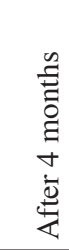 & 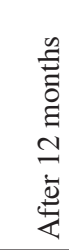 & 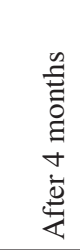 & 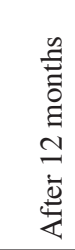 & $\begin{array}{l}\frac{5}{0} \\
\frac{0}{3} \\
\frac{\pi}{5} \\
0 \\
0 \\
0\end{array}$ & 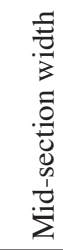 & $\begin{array}{l}\text { w } \\
0 \\
0 \\
0 \\
0 \\
0 \\
0 \\
0 \\
0 \\
0\end{array}$ & 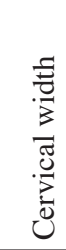 & 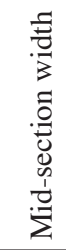 & $\begin{array}{l}\text { s } \\
0 \\
0 \\
0 \\
0 \\
0 \\
0 \\
0 \\
0 \\
0\end{array}$ & $\begin{array}{l}\frac{5}{0} \\
\frac{0}{3} \\
\frac{\pi}{0} \\
0 \\
0 \\
0\end{array}$ & 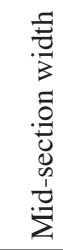 & $\begin{array}{l}\text { Dे } \\
0 \\
0 \\
0 \\
0 \\
0 \\
0 \\
0 \\
0\end{array}$ \\
\hline \multirow{6}{*}{ 气̊̆ } & 1 & 3 & 3 & 0.00 & 0.00 & 1.7 & 2 & 0.00 & 1.7 & 2 & 0.00 & 1.7 & 2 & 0.00 \\
\hline & 2 & 3 & 2 & 0.00 & 0.00 & 0.9 & 1.6 & 0.00 & 0.9 & 1.6 & 0.00 & 0.9 & 1.6 & 0.00 \\
\hline & 3 & 3 & 3 & 0.00 & 0.00 & 0.7 & 1.2 & 0.00 & 0.7 & 1.2 & 0.00 & 0.7 & 1.2 & 0.00 \\
\hline & 4 & 3 & 2 & 0.00 & 0.00 & 1.2 & 1.8 & 0.00 & 1.2 & 1.8 & 0.00 & 1.2 & 1.8 & 0.00 \\
\hline & 5 & 3 & 2 & 0.00 & 0.00 & 1.7 & 2.8 & 0.00 & 1.7 & 2.8 & 0.00 & 1.7 & 2.8 & 0.00 \\
\hline & 6 & 3 & 3 & 0.00 & 0.00 & 1 & 2.4 & 0.00 & 1 & 2.4 & 0.00 & 1 & 2.4 & 0.00 \\
\hline \multirow{6}{*}{ 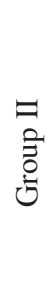 } & 1 & 3 & 2 & 0.00 & 0.00 & 1.2 & 2.1 & 0.00 & 1.2 & 2.1 & 0.00 & 1.2 & 2.1 & 0.00 \\
\hline & 2 & 3 & 3 & 0.00 & 0.00 & 1.3 & 1.7 & 0.00 & 1.3 & 1.7 & 0.00 & 1.3 & 1.7 & 0.00 \\
\hline & 3 & 3 & 3 & 0.00 & 0.00 & 2.3 & 3.4 & 0.00 & 2.3 & 3.4 & 0.00 & 2.3 & 3.4 & 0.00 \\
\hline & 4 & 3 & 2 & 0.00 & 0.00 & 2.2 & 3.2 & 0.00 & 2.2 & 3.2 & 0.00 & 2.2 & 3.2 & 0.00 \\
\hline & 5 & 3 & 3 & 0.00 & 0.00 & 2.2 & 3.1 & 0.00 & 2.2 & 3.1 & 0.00 & 2.2 & 3.1 & 0.00 \\
\hline & 6 & 3 & 3 & 0.00 & 0.00 & 2.3 & 3.4 & 0.00 & 2.3 & 3.4 & 0.00 & 2.3 & 3.4 & 0.00 \\
\hline \multirow{6}{*}{ 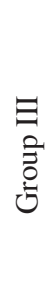 } & 1 & 3 & 3 & 0.00 & 0.00 & 1.2 & 2.4 & 0.00 & 1.2 & 2.4 & 0.00 & 1.2 & 2.4 & 0.00 \\
\hline & 2 & 3 & 2 & 0.00 & 0.00 & 2.9 & 3.7 & 0.00 & 2.9 & 3.7 & 0.00 & 2.9 & 3.7 & 0.00 \\
\hline & 3 & 3 & 3 & 0.00 & 0.00 & 2.1 & 2.8 & 0.00 & 2.1 & 2.8 & 0.00 & 2.1 & 2.8 & 0.00 \\
\hline & 4 & 3 & 2 & 0.00 & 0.00 & 1.9 & 2.7 & 0.00 & 1.9 & 2.7 & 0.00 & 1.9 & 2.7 & 0.00 \\
\hline & 5 & 3 & 3 & 0.00 & 0.00 & 1.4 & 2.6 & 0.00 & 1.4 & 2.6 & 0.00 & 1.4 & 2.6 & 0.00 \\
\hline & 6 & 3 & 3 & 0.00 & 0.00 & 2 & 2.9 & 0.00 & 2 & 2.9 & 0.00 & 2 & 2.9 & 0.00 \\
\hline
\end{tabular}


TABLE (2) Statistical analysis results

\begin{tabular}{|c|c|c|c|c|c|}
\hline $\begin{array}{l}\text { Follow up } \\
\text { parameter }\end{array}$ & \multicolumn{2}{|c|}{ Statistical analysis test used } & $\begin{array}{c}\text { Group I } \\
\text { comparison } \\
\text { between } 4 \text { and } 12 \\
\text { months }\end{array}$ & $\begin{array}{c}\text { Group II } \\
\text { comparison } \\
\text { between } 4 \text { and } 12 \\
\text { months }\end{array}$ & $\begin{array}{c}\text { Group III } \\
\text { comparison } \\
\text { between } 4 \text { and } 12 \\
\text { months }\end{array}$ \\
\hline \multirow{3}{*}{$\begin{array}{c}\text { Shape of the } \\
\text { papillae }\end{array}$} & \multirow{3}{*}{$\begin{array}{l}\mathrm{T} \text { Test for } 2 \\
\text { Dependent } \\
\text { Means }\end{array}$} & $\mathrm{t}$ & -2.236 & -1.581 & -1.581 \\
\hline & & $\mathrm{p}$ & .075 & .17 & .17 \\
\hline & & Significance at $\mathrm{p}<.05$ & not significant & not significant & not significant \\
\hline \multirow{3}{*}{$\begin{array}{l}\text { Gingival } \\
\text { recession }\end{array}$} & \multirow{3}{*}{$\begin{array}{l}\text { Kruskal-Wallis } \\
\text { test }\end{array}$} & $\mathrm{t}$ & 39 & 39 & 39 \\
\hline & & $\mathrm{p}$ & 1 & 1 & 1 \\
\hline & & Significance at $\mathrm{p}<.05$ & not significant & not significant & not significant \\
\hline \multirow{2}{*}{$\begin{array}{l}\text { Labial bone } \\
\text { plate thickness }\end{array}$} & \multirow{2}{*}{$\begin{array}{l}\text { Mann-Whitney } \\
\text { U-test. }\end{array}$} & $\begin{array}{c}\text { The critical value of } U \\
\text { at } p<.05 \text { is } 5\end{array}$ & 18 & 18 & 18 \\
\hline & & Significance at $\mathrm{p}<.05$ & not significant & not significant & not significant \\
\hline \multirow{2}{*}{$\begin{array}{l}\text { Labial bone } \\
\text { plate vertical } \\
\text { resorption }\end{array}$} & \multirow{2}{*}{$\begin{array}{l}\text { Mann-Whitney } \\
\text { U-test. }\end{array}$} & $\begin{array}{c}\text { The critical value of } U \\
\text { at } p<.05 \text { is } 5\end{array}$ & 18 & 18 & 18 \\
\hline & & Significance at $p<.05$ & not significant & not significant & not significant \\
\hline
\end{tabular}

radiologist having over 20 years of experience, with a two weeks' interval. No significant changes were found in the thicknesses of the labial bone plate, which also did not show any vertical resorption in any of the cases in this study, which meant that the socket shield was able to maintain the labial plate of bone as if no tooth extraction was done.

\section{DISCUSSION}

This study used the socket shield technique as a new maneuver to stop maxillary anterior alveolar bone loss, 3 different implant systems were placed immediately after extraction with a bone graft placed in the intervening space between the implant and the socket shield. Unassisted socket healing in the form of an extraction socket receiving an immediate implant with neither a bone graft nor a socket shield, serving as the negative control, was not included for ethical reasons.

Gharpure and Bhatavadekar ${ }^{1}$ histologic study of the socket-shield technique documented rapid bone loss, failure of osseointegration, formation of cementum, and a periodontal ligament-like fibrous tissue on implant surfaces in proximity to the shield which resulted in weakening in the biologic proof of principle of this technique. Heggeler et al ${ }^{10}$ further added that solid conclusions about socket preservation after teeth extraction in humans are difficult to make because dimensional changes following bone resorption may still lead to a change in the socket height and width.

However, several other studies were in favor of the socket shield technique; Gluckman et al $^{3}$ in a 100 patient case series reporting on implant survival with the socket-shield technique found comparable survival rate to conventional delayed and immediate implants at mid-term follow-up with rare complication rate. Siormpas et al ${ }^{4}$ further added that the socket shield increases the durability of the implant service by preserving their surrounding tissues. Also, Barakat et al ${ }^{5}$ found that this technique maintained the buccal bone plate, and Mitsias et al ${ }^{6}$ 
human histologic study proved that this hypothesis was valid for immediate implants in function with no assistance of other ridge augmentation techniques.

The third generation bioactive glass, calcium phosphosilicate, utilized in this study was proven to result in vital bone formation after a 4 to 5 months healing period and tended to increase over time as found by Kesmas et al, ${ }^{15}$ Kotsakis et al, ${ }^{17,}{ }^{18}$ and Gonshor et al ${ }^{19}$ who reported that this relatively fast healing may provide a clinical advantage for implant osseointegration. In addition, the findings of Bembi et al ${ }^{20}$ revealed that the bioactive calcium phosphosilicate was biocompatible and safe to use without causing any inadvertent tissue response or antigenic reaction for the treatment of intra bony defects once good oral hygiene and inflammationfree periodontal tissue were maintained in the postoperative phase. These findings were further confirmed by Mahesh et al ${ }^{21,25}$ and Babbush and Kanawati ${ }^{22}$ who have shown that this bioactive glass paste consistency allowed faster and proper filling of the peri implant defects.

In this study, stabilization of the graft material by placing a contoured healing abutment was recommended by Tarnow et $\mathrm{al}^{2}$ as it was able to minimize the facial- palatal dimensional changes of sockets receiving immediate implants, Sarnachiaro et al ${ }^{32}$ and Harshakumar et al ${ }^{58}$ further added that this approach maintained the gingival architecture and helped produce a better emergence profile for better esthetics of the definitive restorations.

Three dental implant systems were used in this study, the Biohorizon Laser-Lock, Nobel biocare Nobel Active, and the Adin Touareg-S implants, all have achieved good primary stability, successful osseointegration, and none of them was lost during the whole period of the study.

The success of Biohorizon implants immediate placement in the first group of the current work was also reported by Farronato at al ${ }^{31}$ who used the same type of implants in thirty-nine patients that had more significant clinical attachment level and less peri-implant crestal bone loss than the other 38 non-Laser-Lok implants. Additionally, in two studies by Guarnieri et al ${ }^{33,35}$ it was found that the laser-micro grooving surface on this implant neck module provided better soft tissue attachment and reduced peri-implant bone loss in anterior maxilla immediate implants which make it a predictable option for well-selected patients. Similarly, the same results were obtained by Mangano et al ${ }^{36}$ and Becker et al ${ }^{38}$ in studies having no control group and comprising a larger number of patients respectively.

In agreement with Singh et al ${ }^{41}$ the Adin Touareg-S dental implants used for group II in this study were also reported as reliable treatment option for patients requiring immediate implant placement, further the ability of Adin implants to obtain good bone anchorage and primary stability was reported by Alam et al, ${ }^{45}$ whereas secondary stability achieved by these implants was referred by Jain and Gaur, ${ }^{46}$ and Guastaldi et al ${ }^{47}$ to its surface modified plasma treatment which enhanced the bone remodeling compared to their control group.

Kielbassa et al ${ }^{48}$ and Arnhart et al ${ }^{51}$ reported similar results about the Nobel Active implants, used in the third group of this study, in having stable levels of soft tissues and bone for 12 months after loading. The same conclusions were made by Cristalli et al,,${ }^{52}$ Kan et al, ${ }^{53}$ Moretto et al, ${ }^{55}$ and Bell and Bell ${ }^{56}$ who reported that with proper selection of patients, and meticulous surgical and prosthetic protocols, Nobel Active implants can achieve the desired primary stability in fresh extraction sockets and long term soft and hard tissue dimensional stability as compared to the conventional delayed placement of the dental implants. however, Cosyn et al ${ }^{49}$ reported that the immediate Nobel Active implants placement is not recommended for daily practice as it had mid-facial recession and resulted in compromised esthetics in 8 of the carefully selected 17 patients, who received this treatment by 
experienced clinicians.

This study also used screwed rather than cemented definitive prostheses, Shadid and Sadaqa ${ }^{81}$ reported that each of these methods of retention has its own merits for being used in certain clinical scenarios, however, Wittneben et al ${ }^{82}$ reported that screw-retained prostheses had less technical errors, and in another research ${ }^{84}$ recommended to use the screw retained principle to avoid an additional risks of cement contaminants, which were reported by Francis and Pillai ${ }^{83}$ to significantly increase the onset of vertical bone loss.

The CBCT used in this study has become frequently used in clinical research, however, Molen ${ }^{66}$ emphasized that CBCT studies making small measurements are liable to misinterpretation due the reduced image resolution as compared to that of periapical radiography that was further found by Dave et al ${ }^{63}$ to be better at diagnosing a peri-implant defects than the CBCT when the peri-implant space was $0.35 \mathrm{~mm}$ or smaller. On the other hand, and in accordance with the methods and results of the current work, several other studies used the CBCT for evaluations of labial alveolar bone thickness and corresponding vertical resorption as measured from the implant shoulder to the alveolar ledge such as that of Miyamoto and Obama, ${ }^{64}$ or simply the mean gain in labial plate thickness such as that of Sarnachiaro et al, ${ }^{32}$ and Leung. ${ }^{65}$ Furthermore, Timock et al ${ }^{67}$ and Kamburoglu et al ${ }^{71}$ investigated the accuracy and reliability of CBCT images through comparisons with direct measurements, and concluded that CBCT measurements did not differ significantly from direct measurements. Based on these studies, it was concluded that the CBCT was a reliable method for evaluation of post-operative results, and also a preoperative analysis tool as recommended by El Nahass and Naiem. ${ }^{75}$

In conclusion, the socket shield technique was found to maintain the pre-operative dimensions of the labial plate of bone and its overlying soft tissues with improved and maintained pink esthetics with the 3 different dental implant systems used, in addition, the custom made healing abutment helped the maintenance of interdental papillae and the production of an emergence profile which can provide long-term esthetic benefits. However, this technique required careful patients' selection, proper treatment planning and follow-up, and is considered highly sensitive.

\section{RECOMMENDATIONS}

After conducting this study, the followings can be recommended:

1. Longer clinical follow-up periods and comparison with negative control groups.

2. The use of this technique in restoration of multiple teeth and in situations where the implants are subjected to different loading conditions such as beneath over dentures.

3. The provision for the use of double socket shields.

\section{REFERENCES}

1. Gharpure A. S. and Bhatavadekar N. B. "Current evidence on the socket-shield technique: a systematic review," Journal of Oral Implantology, 2017; Vol. XLIII (5):395403.

2. Tarnow DP, Chu SJ, Salama MA, Stappert CF, Salama H, Garber DA, et al. Flapless postextraction socket implant placement in the esthetic zone: part 1. The effect of bone grafting and/or provisional restoration on facial-palatal ridge dimensional change-a retrospective cohort study. Int J Periodontics Restorative Dent 2014; 34:323-31.

3. Gluckman H, Salama M, Du Toit J. A retrospective evaluation of 128 socket-shield cases in the esthetic zone and posterior sites: Partial extraction therapy with up to 4 years follow-up. Clin Implant Dent Relat Res 2018; 20: 122-129.

4. Siormpas KD, Mitsias ME, Kontsiotou-Siormpa E, Garber D, Kotsakis GA. Immediate implant placement in the esthetic zone utilizing the "rootmembrane" technique: clinical results up to 5 years post loading. Int J Oral Maxillofac Implants. 2014; 29:1397-1405.

5. Barakat DA, Hassan RS, Riham M. Eldibany RM. Evaluation of the socket shield technique for immediate implantation. Alexandria Dental Journal. 2017; 42:155-161. 
6. Mitsias ME, Siormpas KD, Kotsakis GA, Ganz SD, Mangano C, Iezzi G. The root membrane technique: Human histologic evidence after five years of function. Biomed Res Int 2017; 2017: 7269467.

7. Walid MA. 3-Dimensional Volumetric Analysis of Double Socket-shield for Maximum Tissue Preservation at Immediate Implant Replacement of Multi-Rooted Teeth, A Case Report. International Journal of Dental Sciences and Research, 2018, Vol. 6, No. 3, 58-66.

8. Tarnow, DP \& Chu, SJ. Human histological verification of osseointegration of an immediate implant placed into a fresh extraction socket with excessive gap distance without primary flap closure, graft, or membrane: a case report. International Journal of Periodontics \& Restorative Dentistry. 2011; 31: 515-21.

9. Avila-Ortiz G, Elangovan S, Kramer KW, Blanchette D, Dawson DV. Effect of alveolar ridge preservation after tooth extraction: a systematic review and meta-analysis. J Dent Res 2014; 93:950-958.

10. Ten Heggeler JMAG, Slot DE, Van der Weijden GA. Effect of socket preservation therapies following tooth extraction in non-molar regions in humans: a systematic review. Clin. Oral Impl. Res. 22, 2011; 779-788.

11. Vignoletti F, Matesanz P, Rodrigo D, Figuero E, Martin C, Sanz M. Surgical protocols for ridge preservation after tooth extraction. A systematic review. Clin. Oral Impl. Res. 23(Suppl. 5), 2012, 22-38.

12. Kotsakis G, Chrepa V, Marcou N, Prasad H, Hinrichs J. Flapless alveolar ridge preservation utilizing the "socketplug" technique: Clinical technique and review of the literature. J Oral Implantol. 2012; 3:24-30.

13. Horvath A, Mardas N, Mezzomo LA, Needleman IG, Donos N. Alveolar ridge preservation. A systematic review. Clin Oral Investig. 2013; 201217:341-363.

14. Tomlin EM, Nelson SJ, Rossmann AJ. Ridge preservation for implant therapy: a review of the literature, Open Dent. J. 8 (Suppl 1-M4) (2014) 66-76 1874-2106.

15. Kesmas, S., Swasdison, S., Yodsanga, S., Sessirisombat, S. \& Jansisyanont, P. Esthetic alveolar ridge preservation with calcium phosphate and collagen membrane: preliminary report. Oral Surgery, Oral Medicine, Oral Pathology, Oral Radiology and Endodontics. 2010; 110: e24-e36.

16. Masaki C, Nakamoto T, Mukaibo T, Kondo Y, Hosokawa R. Strategies for alveolar ridge reconstruction and preservation for implant therapy. J Prosthodont Res 2015; 59:220-8.
17. Kotsakis GA, Joachim F, Saroff SA, Mahesh L, Prasad H, Rohrer M. Histomorphometric evaluation of a calciumphosphosilicate bone substitute in extraction sockets. Int $\mathrm{J}$ Periodontics Restorative Dent. 2014; 34:233-239.

18. Kotsakis GA, Salama M, Chrepa V, Hinrichs J, Gaillard P. A randomized, blinded, controlled clinical study of particulate Anorganic Bovine Bone Mineral and Calcium Phosphosilicate Putty bone substitutes for alveolar ridge preservation. Int J Oral Maxillofac Implants. 2014; 29:141-51.

19. Gonshor, A., Saroff, S.A., Anderegg, C.R., Joachim, F.P.C., Charon, J.A., Prasad, H. \& Katta, S. Histologic and clinical evaluation of a bioactive calcium phosphosilicate bone graft material in postextraction alveolar sockets. International Journal of Oral Implantology and Clinical Research. 2011; 2: 79-84.

20. Bembi NN, Bembi S, Mago J, Baweja GK, Baweja PS. Comparative Evaluation of Bioactive Synthetic NovaBone Putty and Calcified Algae-derived Porous Hydroxyapatite Bone Grafts for the Treatment of Intrabony Defects. Int J Clin Pediatr Dent 2016;9(4):285-290.

21. Mahesh L, Kotsakis G, Venkataraman N, Shukla S, Prasad H. Ridge preservation with the socket-plug technique utilizing an alloplastic putty bone substitute or a particulate xenograft: a histological pilot study. J Oral Implantol. 2015; Vol. XLI/No. Two: 178-183.

22. Babbush CA, Kanawati A: Clinical evaluation of 262 osseointegrated implants placed in sites grafted with calcium phosphosilicate putty: a retrospective study. J Oral Implantol. 2015; 41(1): 63e69.

23. Asmita, Gupta V, Bains VK, Singh GP, Jhingran R. Clinical and cone beam computed tomography comparison of NovaBone Dental Putty and PerioGlas in the treatment of mandibular class II furcations. Indian J Dent Res. 2014; 25:166-73.

24. Schallenberger MA, Rossmeier K, Lovick HM, Meyer TR, Aberman HM, and Juda GA. Comparison of the Osteogenic Potential of OsteoSelect Demineralized Bone Matrix Putty to NovaBone Calcium- Phosphosilicate Synthetic Putty in a Cranial Defect Model. J. Craniofac. Surg. 2014; 25 (2): 657-661.

25. Mahesh L, Narayan TV, Bali P, Shukla S. Socket preservation with alloplast: discussion and a descriptive case. J Contemp Dent Pract 2012;13(6):934-7.

26. Quirynen, M., Van Assche, N., Botticelli, D. \& Berglundh. How does the timing of implant placement to extraction affect outcome? The International Journal of Oral \& Maxillofacial Implants. 2007; 22 (Suppl.): 203-223. 
27. Felice P, Soardi E, Piattelli M, Pistilli R, Jacotti M, Esposito M. Immediate non-occlusal loading of immediate postextractive versus delayed placement of single implants in preserved sockets of the anterior maxilla: 4-month postloading results from a pragmatic multicentre randomised controlled trial. European Journal of Oral Implantology. 2011; 4:329-44.

28. Chrcanovic BR, Albrektsson T, Wennerberg A. Dental implants inserted in fresh extraction sockets versus healed sites: a systematic review and meta-analysis. Journal of Dentistry. 2015; 43:16-41.

29. Colombo JS, Satoshi S, Okazaki J, Crean SJ, Sloan AJ, et al. In vivo monitoring of the bone healing process around different titanium alloy implant surfaces placed into fresh extraction sockets. J Dent. 2012; 40: 338-346.

30. Bilhan H, Geckili O, Mumcu E, Bozdag E, Sunbuloglu E, Kutay O. Influence of surgical technique, implant shape and diameter on the primary stability in cancellous bone. $\mathrm{J}$ Oral Rehabil. 2010;37(12):900-7.

31. Farronato D, Mangano F, Briguglio F, Iorio-Siciliano V, Riccitiello F, Guarnieri R. Influence of Laser-Lok surface on immediate functional loading of implants in singletooth replacement: A 2-year prospective clinical study. Int J Periodontics Restorative Dent. 2014; 34:79-89.

32. Sarnachiaro, G.O., Chu, S.J., Sarnachiaro, E., Gotta, S.L., Tarnov, D.P. Immediate implant placement into extraction sockets with labial plate dehiscence defects: a clinical case series. Clin. Implant Dent. Relat. Res. 2016; 18: 821-829,

33. Guarnieri, R., Serra, M., Bava, L., Farronato, D., IorioSiciliano, V. \& Grande, M. (2014) The impact of laser microtexturing collar designs on crestal bone level, and clinical parameters under various placement and loading protocols. International Journal of Oral \& Maxillofaccial Implants 29: 354-363.

34. Guarnieri, R., Ceccherini, A. \& Grande, M. Single-tooth replacement in the anterior maxilla by means of immediate implantation and early loading: clinical and aesthetic results at 5 years. Clinical Implant Dentistry and Related Research. 2015; 17: 314-326.

35. Guarnieri, R., Belleggia, F. \& Grande, M. Immediate versus delayed treatment in the anterior maxilla using single implants with a lasermicrotextured collar: 3-year results of a case series on hard- and soft-tissue response and esthetics. Journal of Prosthodontics. 2016; 25: 135145.

36. Mangano, F., Mangano, C., Ricci, M., Sammons, R.L., Shibli, J.A. \& Piattelli, A. Singletooth morse taper connection implants placed in fresh extraction sockets of the anterior maxilla: an aesthetic evaluation. Clinical Oral Implants Research. 2012; 23: 1302-1307.

37. Nevins M, Nevins ML, Camelo M, Boyesen JL, Kim DM. Human histologic evidence of a connective tissue attachment to a dental implant. Int $\mathrm{J}$ Periodontics Restorative Dent. 2008; 28:111-121.

38. Becker CM, Wilson TG Jr, Jensen OT. Minimum criteria for immediate provisionalization of single-tooth dental implants in extraction sites: a 1-year retrospective study of 100 consecutive cases. J Oral Maxillofac Surg. 2011; 69:491-7.

39. Bhargava D, Thomas S, Pandey A, Deshpande A, Mishra SK. Comparative study to evaluate bone loss during osteotomy using standard drill, bone trephine, and alveolar expanders for implant placement. J Indian Prosthodont Soc. 2018; 18:226-30.

40. Thumati P, Padmaja S, S aritha H. An evaluation of topographic changes in peri-implant hard and soft-tissues using a standardized technique.J Dent Implant 2013;3:91100 .

41. Singh M, Kumar L, Anwar M, Chand P. Immediate dental implant placement with immediate loading following extraction of natural teeth. Natl J Maxillofac Surg. 2015; 6:252-5.

42. Chantelle Van Graan. "Immediate Implant Placement in the Anterior Maxilla with Customized Impression Coping: A Clinical Case Presentation". EC Dental Science 9.5 (2017): 197-206.

43. Basnet BB, Immediate Placement of Dental Implant on Freshly Extracted Socket: A Case Report from B. P. Koirala Institute of Health Sciences, Dharan. BJHS 2017; 2: 230-233.

44. Boora P, Rathee M, Bhoria M. Effect of platelet rich fibrin (PRF) on peri-implant soft tissue and crestal bone in onestage implant placement: a randomized controlled trial. J Clin Diagn Res. 2015; 9(4): ZC18-ZC21.

45. Alam M.N., Anand N., Chandrasekaran S.and Kovendhan Y. Is primary stability the gold standard factor in implant success. Dent Hypotheses. 2014; 5:70-4.

46. Jain D, Gaur G. Flapless implant placement: a case report. J Oral Implantol. 2014; 40: 321-324.

47. Guastaldi FP, Yoo D, Marin C, Jimbo R, Tovar N, ZanettaBarbosa D, et al.Plasma treatment maintains surface energy of the implant surface and enhances osseointegration. Int J Biomater. 2013; 2013:354125. 
48. Kielbassa AM, Martinez-de Fuentes R, Goldstein M, Arnhart C, Barlattani A, Jackowski J, et al. Randomized controlled trial comparing a variable-thread novel tapered and a standard tapered implant: interim one-year results. The Journal of Prosthetic Dentistry. 2009; 101:293-305.

49. Cosyn J, Eghbali A, Hermans A, Vervaeke S, De Bruyn H, Cleymaet R. A 5-year prospective study on single immediate implants in the aesthetic zone. J Clin Periodontol 2016; 43: 702-709.

50. Slagter KW, Meijer HJA, Bakker NA, Vissink A, Raghoebar GM. Feasibility of immediate placement of singletooth implants in the aesthetic zone: a 1-year randomized controlled trial. J Clin Periodontol 2015; 42:773-782.

51. Arnhart C, Kielbassa AM, Martinez-de Fuentes R, Goldstein M, Jackowski J, Lorenzoni M et al. Comparison of variable-thread tapered implant designs to a standard taperedimplant design after immediate loading. A 3-year multicentre randomised controlled trial. Eur $\mathrm{J}$ Oral Implantol. 2012; 5:123-136.

52. Cristalli MP, Marini R, La Monaca G, Sepe C, Tonoli F, Annibali S. Immediate loading of post-extractive singletooth implants: an 1-year prospective study. Clin. Oral Impl. Res. 26, 2015, 1070-1079.

53. Kan, J., Roe, P. \& Rungcharassaeng, K. Effects of implant morphology on rotational stability during immediate implant placement in the esthetic zone. International Journal of Oral and Maxillofacial Implants. 2015; 30: 667-670.

54. de Molon RS, de Avila ED, de Barros-Filho LA, et al. Reconstruction of the alveolar buccal bone plate in compromised fresh socket after immediate implant placement followed by immediate provisionalization. J Esthet Restor Dent. 2015;27(3):122-135.

55. Moretto D, Gargari M, Nordsjo E, Gloria F, Ottria L. Immediate loading: a new implant technique with immediate loading and aesthetics: Nobel Active. Oral Implantol (Rome). 2008;1(2):50-5.

56. Bell C, Bell RE. Immediate restoration of NobelActive implants placed into fresh extraction sites in the anterior maxilla. J Oral Implantol. 2014; 40:455-458.

57. Bruno V,O'Sullivan DB, Badino M, Catapano S.Preserving soft tissue after placing implants in fresh extraction sockets in the maxillary esthetic zone and a prosthetic template for interim crown fabrication: A prospective study. Journal of Prosthetic Dentistry. 2014 Mar;111(3):195-202.

58. Harshakumar K, Deepthi V S, Ravichandran R, Prasanth V. Customized healing abutment for enhancing pink aesthetics in implants. J Dent Implant 2013; 3:172-6.
59. Rodriguez AM, Rosenstiel SF. Esthetic considerations related to bone and soft tissue maintenance and development around dental implants: report of the Committee on Research in Fixed Prosthodontics of the American Academy of Fixed Prosthodontics. J Prosthet Dent 2012; 108:259-67.

60. Bruno V, Badino M, Sacco R, Catapano S. The use of a prosthetic template to maintain the papilla in the esthetic zone for immediate implant placement by means of a radiographic procedure. J Prosthet Dent. 2012; 108:394-7.

61. Cosyn J, De Bruyn H, Cleymaet R. Soft tissue preservation and pink aesthetics around single immediate implant restorations: A 1-year prospective study. Clin Implant Dent Relat Res.2013;15 (6): 847-857.

62. Q. Yan, L.-Q. Xiao, M.-Y. Su, Y. Mei, and B. Shi, "Soft and hard tissue changes following immediate placement or immediate restoration of single-tooth implants in the esthetic zone: A systematic review and meta-analysis", The International Journal of Oral \& Maxillofacial Implants. 2016; 31(6): 1327-1340.

63. Dave M, Davies J, Wilson R, Palmer R. A comparison of cone beam computed tomography and conventional periapical radiography at detecting peri-implant bone defects. Clin. Oral Impl. Res.2013; 24: 671-678.

64. Miyamoto Y, Obama T. Dental cone beam computed tomography analyses of postoperative labial bone thickness in maxillary anterior implants: Comparing immediate and delayed implant placement. Int J Periodontics Restorative Dent 2011; 31:215-225.

65. Leung CC, Palomo L, Griffith R, Hans MG. Accuracy and reliability of cone-beam computed tomography for measuring alveolar bone height and detecting bony dehiscences and fenestrations. Am J Orthod Dentofacial Orthop 2010; 137: S109-119.

66. Molen AD. Considerations in the use of cone-beam computed tomography for buccal bone measurements. Am J Orthod Dentofacial Orthop. 2010;137(4 Suppl):S130-S135.

67. Timock A, Cook V, McDonald T, Leo MC, Crowe J, Benninger B, et al. Accuracy and reliability of buccal bone height and thickness measurements from cone-beam computed tomography imaging. Am J Orthod Dentofacial Orthop 2011; 140:734-44.

68. Patcas R, Muller L, Ullrich O, Peltomaki T: Accuracy of conebeam computed tomography at different resolutions assessed on the bony covering of the mandibular anterior teeth. Am J Orthod Dentofacial Orthop. 2012; 141:41-50.

69. Wood R, Sun Z, Chaudhry J, Tee BC, Kim DG, Leblebicioglu B, et al. Factors affecting the accuracy of 
buccal alveolar bone height measurements from conebeam computed tomography images. Am J Orthod Dentofacial Orthop. 2013; 143:353-63.

70. C, KaracaN. Er, A. Gu“ls sahı, O.T. Ko“ seog ${ }^{`} l u$ : Alveolar ridge preservation with a free gingival graft in the anterior maxilla: volumetric evaluation in a randomized clinical trial. Int. J. Oral Maxillofac. Surg. 2015; 44: 774-780.

71. Kamburoglu K, Murat S, Kiliç C, Yüksel S, Avsever H, Farman A, et al. Accuracy of CBCT images in the assessment of buecal marginal alveolar peri-implant defects: effect of field of view. Dentomaxillofac Radiol 2014; 43: 20130332.

72. Morimoto T, Tsukiyama Y, Morimoto K, Koyano K. Facial bone alterations on maxillary anterior single implants for immediate placement and provisionalization following tooth extraction: a superimposed cone beam computed tomography study. Clin. Oral Impl. Res. 26, 2015, 13831389.

73. Wang HM, Shen JW, Yu MF, Chen XY, Jiang QH, He FM. Analysis of facial bone wall dimensions and sagittal root position in the maxillary esthetic zone: a retrospective study using cone beam computed tomography. Int J Oral Maxillofac Implants.2014;29(5):1123-1129.

74. Zekry A, Wang R, Chau ACM, Lang NP. Facial alveolar bone wall width - a cone-beam computed tomography study in Asians. Clin. Oral Impl. Res. 2014;25: 194-206.

75. El Nahass H, Naiem SN. Analysis of the Dimensions of the labial bone wall in the anterior maxilla: a cone-beam computed tomography study. Clin. Oral Impl. Res. 26, 2015, e57-e61.

76. Lee EA, Gonzalez-Martin O, Fiorellini J. Lingualized flapless implant placement into fresh extraction sockets preserves buccal alveolar bone: a cone beam computed tomography study. Int $\mathrm{J}$ Periodontics Restorative Dent 2014: 34: 61-68.

77. Fuentes R, Flores T, Navarro P, Salamanca C, Beltra'n V, Borie E. Assessment of buccal bone thickness of aesthetic maxillary region: a cone beam computed tomography study. J Periodontal Implant Sci. 2015;45: 162- 168.
78. Ho DSW, Yeung SCH, Zee KY, Curtis B, Hell P, Tumuluri V. Clinical and radiographic evaluation of Nobel Active TM dental implants. Clin. Oral Impl. Res. 2013; 24: 297 304

79. Scarfe WC, Farman AG. Interpreting CBCT Images for implant assessment: Part 1-Pitfalls in image interpretation. Australas Dent Pract. 2010 July-August; 20:106-14.

80. Jemt $\mathrm{T}$. Regeneration of gingival papillae after singleimplant treatment. Int $\mathrm{J}$ Periodontics Restorative Dent 1997; 17:326-33.

81. Shadid R, Sadaqa N. A comparison between screw- and cementretained implant prostheses. A literature review. J Oral Implantol 2012; 38:298-307.

82. Wittneben JG, Millen C, Bragger U. Clinical performance of screw- versus cement-retained fixed implant-supported reconstructions - a systematic review. Int $\mathrm{J}$ Oral Maxillofac Implants. 2014; 29:84-98.

83. Francis L, Pillai SB. Rate of marginal bone loss around screw-retained and cement retained single implant prostheses - a split mouth study. Indian Journal of Applied Research.2018;7: 10.

84. Wittneben J-G, Joda T, Weber H-P, Br€agger U. Screw retained vs. cement retained implant-supported fixed dental prosthesis. Periodontol 2000 2017: 73: 141-151.

85. Carlsson L, Rostlund T, Albrektsson B, Albrektsson T. Implant fixation improved by close fit. Cylindrical implantbone interface studied in rabbits. Acta Orthop Scand. 1988; 59:272 275.

86. Knox R, Caudill R, Meffert R. Histologic evaluation of dental endosseous implants placed into surgically created extraction defects. Int J Periodontics Restorative Dent. 1991; 11:365-375.

87. Botticelli D, Berglundh T, Buser D, Lindhe J. The jumping distance revisited: An experimental study in the dog. Clin Oral Implants Res. 2003; 14:35-42.

88. Botticelli D, Berglundh T, Buser D, Lindhe J. Appositional bone formation in marginal defects at implants. Clin Oral Implants Res. 2003; 14:1-9. 